\title{
Archaism and Nationalism of the Principles of Political Identity of Pahlavi I
}

\author{
Mostafa Samiee Zenoozian ${ }^{1}$, Davood Esfehanian ${ }^{1}$, Hosein Aliyari $^{1}$ \& Assadallah Salehi Panahi ${ }^{1}$ \\ ${ }^{1}$ Department of Humanities, Shabestar Branch, Islamic Azad University, Shabestar, Iran \\ Correspondence: Davood Esfehanian, Department of Humanities, Shabestar Branch, Islamic Azad University, \\ Shabestar, Iran. Te1: 98-91-4413-1064. E-mail: davoodesfehniyan@gmail.com
}

Received: March 21, 2016 Accepted: July 1, 2016 On line Published: July 31, 2016

doi:10.5539/jpl.v9n6p81

URL: http://d x.doi.org/10.5539/jpl.v9n 6p81

\begin{abstract}
Nationalism was the main axes of the first Pahlavi era that was followed by using the Persian language and ethnicity, paying attention to the historical past and relying on the antiquity were of its manifestations the result of which was crystallized in the homeland patriotis $\mathrm{m}$. In this age of homeland, close bond component was king worship and archais m. Reza Shah's government, by leading the intellectuals sought to replace Imperial ideology of nationalis $\mathrm{m}$ with the Iranian and Islamic culture and rests the legitimacy of his regime on it. One of the features and characteristics of the Pahlavi regime was the emphasis on the idea of nationalist glory and honor of the Zoroastrian religion of pre-Islamic Iran and the Persian language worshiped by that time.This article aims at the crystallization phenomenon of nationalis $m$ and ancient Persian language and ethnicity importance of convergence in the approach of the Iranian (Aryan era) in the first Pahlavi era and investigated the implications and intentions of the founders approach.
\end{abstract}

Keywords: first Pahlavi, nationalism, Persian language, Iran ian nations, Aryan

\section{Introduction}

The first Pahlavi relied on nationalis $m$ and modernization at the same time as the approach that should transform Iran. Approaches that somehow directly followed by the propaganda system including newspapers and magazines, publications and books, especially history books in the forma educational system was affected by it. This approach was accompanied by two features. The first feature is magnified in the hist ory of ancient Iran and the Aryans, on the one hand was trying to neglect and even humiliate Islamic civilization - Iran and Iran after the Is lamic era, and the other to emphasize on aspects of ancient culture which had occasion to the needs of the Pahlavi dynasty. The worship of the monarchy and the king's friendship, even the king-worship was seen as part of Iranian culture and intensity of publicity so that this case seemed necessities and axioms. The second feature is that with contempt customs, language and identity of different ethnic groups in Iran, a policy of ethnic and cultural integration was adopted.

There are some works about nationalism of the Pahlavi literature; among them two works can be pointed to: archaism in contemporary Iran written by Reza Bigdelo, Iranian identity and genealogy, written by Mohammad Ali Akbari, in the first book the author investigated archaism in contemporary thinkers and in the second, the author revolves around the identity of the Qajar and Pahlavi. Therefore, the present article seeks to investigate the rise of nationalis $m$ and archais $m$ in the first Pahlavi era with the assumption that the pursuit of this policy followed the political legitimacy of the first Pahlavi.

The author has tried in the first place, to provide theoretical answer on what nationalism is, and second to explore and recover the manifestations in intellectual thought of Qajar period and Constitutional Era and third, to scrutinize and review newspapers and magazines; works of politicians supporting homeland patriotis $\mathrm{m}$ and friendship, Persian language; Aryan races; archaism and friendship with Shah and the implications of this approach.

\section{Nationalism and Nationalist Views before the First Pahlavi Dynasty}

\section{Nationalism:}

Nationalism (nationalism or nationalis m) was interpreted as a collective consciousness, the consciousness of belonging to a nation or national consciousness, which often cause the sense of loyalty, passion and attachment 
of the constituent elements of the nation, the race, language, tradition, habits and social and moral values and the culture in general(Ashuri, 1997: 319). The transformations of nationalism rooted in European societies and influenced by intellectual, political and social European backgrounds had spread to other countries, including countries in Asia, but found out that the East and West differ in the acceptance and emergence of nationalis $m$.

News paper was the entry of nationality and patriotism to Iran during the Qajar period by intellectuals. Iran and Europe are gradually awakened the idea of progress and developments in Europe advancements. In addition to concepts such as law, changes in the political system and also the is sue of homeland and nation were raised in the works of some Nasseri's era intellectuals. They were discussed in the works of Mirza Fatali Akhundzadeh, Jalal al-Din Mirza Qajar, Mostashar Tabrizi, Mirza Agha Khan Kermani and Talibof.

The revival of the ancient past of Iran with emphasis on the centrality of the Persian language in the writings of Akhoondzadeh is mainly accompanied by Arab hatred and has been emphasized in the work of the Aga Khan Kermani to Zoroastrianism as the most complete and most advanced ancient ritual and the Persian language courses far belong to Iranians. (Adamiyyat1979: 377-379)

On the one hand, the newspapers such as Akhtar and Vatan offer a new concept of homeland and link their content with ancient and mythical kingdom Iran. In the constitutional era newspapers, shares homeland discourse with a new metaphor having the concept of home mother and mother homeland. The establishment of the constitutional system and the rise of government, give the nation a new concept, and the amendment of its constitution and state law - new Iranian nation was formed and the role of nation was highlighted. But the political situation after the second parliamentary caused intellectuals to know powerful govern ment as the only remedy available in the approach. (Akbari, 2006: 65)

Nationalism gains a certain concept in this period of time that emphasize on archaism which relied on the rise of authoritarian rulers and rebirth of the father of the country. Thus, elites and intellectuals in the years after World War I consider the establishment of a powerful state with a dictatorship of scientists and practitioners as the only way to save the country (Moshfegh Kaze mi, 1925, 3. 11, No. 1). Setting the vote of the people with this mindset, expressing affection and superiority on Iranian race and Persian language, especially considering the articulation of ancestors and ancestors in ancient times and the obligation in giving to the other social customs were viewed as a road map.

\section{Global Ideas of Nationalism and Its Impact on Iran}

This view is influenced by the emerging idea of development as a conservative revolution that occurred in Germany and Japan. A top conservative revolution and reform, requires certain conditions. First, these reforms require strong leadership that can bring in its wake short-sighted and reactionary elements, in particular the landed gentry. The reformist leaders should have strong governance, especially the military and the police thereby to free itself of the reactionaries and the pressures of radical elements in society and that government becomes independent of community and promotes extreme nationalis m. (Moore, 1979: 31) and considered his nation as the greatest people on earth and give rise to the spirit of nationalis $m$ and ethnicity as the homeland of Nazis $m$ in Germany and fascism in Italy, with its worship of Duce.

The elite wanted to use the Crown's power as a vehicle for reform and modernization of national unity. The most successful conservative regime not only disrupted the old system, but also replaced a new system. Government can help to the development of the industry in many ways and gather capital accumulation and mobilization of financial resources as a primary instrument to the creation of industry. The government also plays an important role in taming labor that was so oppressive. The establishment of policies for military and customs incentives for industrial development was important. All of these measures require pulling out resources or manpower from the field of agriculture. (Ibid: 30 )

Intellectuals and political elite after the German Constitutional Revolution were mostly the educated or those influenced by the political climate prevailing in the period after the First World War in Europe and the implementation and comparison of problems and crises in Iranian society and unwanted problems imposed on Iranian society after World War I and Constitution consider resorting to fascism as the way out of emerg ing issues in Europe. Although they were not directly speak of fascism and use the so-called military dictator and Reza Khan Reformer's character, which according to them benefits reform the ideas and intellectual was appropriate for this case and tried to provide the necessary intellectual and thought grounds. Therefore nationalism era was of the require ments of g lobal govern ments. Reza Shah affected by international nationalis $\mathrm{m}$, set his emphasis on the oldest parts of Iran. 


\section{Nationalism and News paper'Approach, Intellectuals Early in the First Pahlavi Period}

Three influential newspapers expressed reformers public demands. Among the newspapers, Iranshahr, which was by Hossein Kazem Zadeh (Abrahamian, 2006: 153) published from 1310 (Iranian Solar Calendar)/1922 to 1306(Iranian Solar Calendar)/1927 proposed nationalist discourse more culturally than others. Site conditions and the lack of his presence in Iran was influential in providing a nationalist range, he believed that education should be responsible for dissemination of nationalist thought and emphasized the importance of the Persian language as the main factor linking the Iranian nation to the ancient period. In 30 Articles, describe the pre-Islamic Iran with the friendly phrases. One of the issues raised and stressed, was the harmful consequences of collectivis m and ethnicity. A lso he believes this view was bad but for honor of I ran, we have to eliminate local divisions, local dialects, costumes, local events and local sentiments (Kazemzadeh, 1925: 1-2). The other newspapers was Farangestan that like Iranshahr emphasize nationalism and pays special attention to issues of race and its three articles were about describing and praising the pre-Islamic Iran and sixteen article on the importance of Persian language and its importance in Iranian nationality. In an article entitled "What do we want", it is stated that although the Iranian press are calling for all type of reforms, the most important thing is Pushing Clergymen of public life and eliminating superstition among the public that only a dictator can do such a reform (Kazemi, 1925: 154-160). Another important journal in the field of extreme nationalism and archais $m$ like other two journals was magazine of the future with the editorial of Mahmoud Afshar that emphasized more on the need for the central government, national identity and the expansion of Persian language among non-Persian communities and the transfer of Turkish and Arab tribes from tribal border to areas inside (Afshar, 1926: 161-174, 559-569).

Foroughi, who is not only political elite, but also cultural elite and has a long history in cultural activities including the writing and publication of books and newspapers, considers common historical past as the main principle and national consensus and was in agreement Rashid Yassami (Foroughi, 1934: 747- 748, No. 114). Ancient-oriented views of Zabih Behruz and Abraham Pourdavood based on the familiarization of culture and civilization of the ancient time and Persian language purification and belonging of the culture to the original language and culture-loving people must not be ignored; a country that was now aware of its greatness past. Reza Shah believes that the best way to establish authority is tendency to nationalis $m$ and archais $m$ and matching with the pre-Isla mic era of Iran's imperial honors (Avery, 2010: 33)

While he and his family pretend to be religion and this was were evident in his religious practices during the prime minister and naming male children in the name of Reza but in the political and imperial power and what led to the previous autocratic governments, a fascination and dependence was shown. Choosing Pah lavi name that alludes to the existence of the five-year-old Parthian and also language that was continued almost a thous and years in northern (Parthian) and southern (Sassanid) Shegl, perhaps was also an inductor in the minds of the Iranian people that especially after a thousand years of Turkish family, Iranian family is now in force and particular trends of archaism is also the image of their efforts (Shaban, 2003: 359-360).

Reza Shah's character and the attention given by some of his people seem natural, and although Reza Shah didn't care public opinion and was not seeking to attract the public and from the perspective of the knowledge and belief, perhaps didn't reach to understanding this concept, but in terms of political legitimacy in a land that has an identity of several thousand years old and in the nation which focuses its national existence at all times and defended their historical existence with tooth and nail by acting as an Iranian dynasty and linked with the historical past, apparently wanted to gain a stronger foothold.

\section{Categories of Persian Race, Language}

Race is also an important issue to the thinkers of the period for the institutionalization of Iranian nationals who devote part of their writings to it. According to the texts, the basis of racial categorization were differences in appearance, hair and skin color, shape of the face and nose and the location of each is distinct from other know white race prior to other races due to the location of the most advanced countries of the world such as the United States of America, England, Germany, France and Russia, as one of the white racial Aryans category, and Iranians have been part of this category and race (Iqbal, 1966: 2- 3)

On the basis of these texts, that the exaggeration element can be seen clearly, the white race is more intelligent and civilized than other races (Sheibani, 1940:2) and introduced as socially higher and more senior than the others, saying that it was the only race that a result of their talents, have superior strength and gain happiness. The dramatic developments in Nazi Germany, Reza Shah in the West tend to be especially strongly influenced by Nazi propaganda about the Aryan race, bring Reza Shah's and Iranian which regard themselves as this race to ecstasy and made Reza Shah interested in getting close to Germany and therefore most of Iran's foreign trade in 
this period were by German and most of Iranian students were sent to study in Germany (Madani, 1996: 120-121).

Elites and intellectuals researchers emphasized on refinement of Persian from other languages, especially Arabic and Turkish, and belonging of the language and the culture to original people. Syed Ahmad Kasravi kidnapped all in this case with pure language and writing books, Azeri language and five-hundred years old Khozestanian history. He writes: "adoring the Iranian language was and is one of our demands for we who are among the Iranians have to write on their language. It would have been far beyond the infected who did not want us to win. We need an orderly and simple and at the same time strong and mighty language. Anyone who wanted could easily learn it. (Kasrawī, 1944: 4) such materials were affected by the idea of nationalism and mixed with a racial bias and in line with the ideology of government nationalis $\mathrm{m}$.

\section{The Categ ory of Archaism and Zoroastrianism}

The first Pahlavi era characterized by nationalism and homeland worship and praise of the King was the outcome of this idea. Among the writers of aspects of archaism, the amazing works of Mohammad Ali Foroughi was influential.

$\mathrm{He}$ is considered as one of the most prominent writers of history books, he considers writing and teaching as the most effective way to give identity to the country and community. In this regard, the old tendencies of Iranian patriotism, relying on the idea of Zoroastrians who sees them as our ancestors, went back to three thous and years ago; praise their faith in Zoroastrianism and their script and language. This is actually Foroughi and his fellow authors efforts for highlighting Iran's past and to enumerate the country during the past greatness of Islam. Another important point of this current approach is the is sue of religion and belief of the people. In this case Iranians believers in Zoroastrianis $\mathrm{m}$, and introduce the new Iranian as followers of Islam. Of course, with a view taken from the ancient nationalism, they are proud of Zoroastrian ancestors and look at it with regret. It seems that they wish to return to the ancient Zoroastrian re lig ion. And also mapping the deline ate symbol, considered it as a beacon of the human spirit. (Qavim, 1929: 6). Given the basic concepts of Zoroas trianism, the four elements of water, earth, fire, wind, water and soil mean the country. Praising the m for Iran ians history is several thous and years old. Services of kings, using the word home, Cyrus, Darius, Ardashir I, Shapur II, Anushiravan, Jacob Laith Seljuk and Malik, Shah Abbas I, the Shah of Iran have been among the greatest in the kingdom. At that time the nation was at the pinnacle of achievement and progress. In light of security and enemies expel by kings whose service is worth the homeland (Sahih, 1942: 32-38). These measures have been made possible because of patriotism and homeland worship by kings. Thereby the initial steps for lin k and integration between the king and the country has been removed which was the beginning of the gradual formation of a sense of homeland friendship with King-friendliness in readers mind, especially children. For example, one of the authors of Shah Abbas I wrote: "He was extremely Justice and served our country and expelled foreigners from Iran and gave safety to the Iranian nation and broadened our country to be perfect (Rams i, 1929: 27)

Historians of the time, in addition to the glorious measures of the kings; highlighting and simulation of Reza Shah's actions through connecting them to the actions of the past Iranian kings, it was induced in reader's mind in such a way that Reza Shah Pahlavi gave safety to homeland and hence was worthy of reverence and love. Thus, Reza Shah was introduced as a super genius who showed his heroism since childhood and the bas is for entering Kazakh army was to serve his country, he pave the ground for the welfare of the nation with putting an end to feudalism chaos (Ibid: 38. 42)

\section{The Link between Patriotism and Shah}

During this period another perspective was ingrained with the view of archaism and homeland discourse and sacrificing of lives in the home was associated with the king-loving. According to this view patriotic loves soil and place of their ancestors and hometown without any conditions and whatever belongs to it whether good or bad, to the point of praise and worship with utmost faith and the presence of heart and give it preference over all others (Nafisi, 1967: 76). For it does not expect any material reward, he must know the king as shadow of God and always inspired by his commandments and worship the king in mind. He should consider the king and his homeland venerable (Ibid). Attributing His Majesty Reza Shah and his canonization as a savior of the country by God to validating and legitimizing the ru le of the Pah lavi was all in the same direction (Yas mi, 1939: 156).

It seems that the early stages of the formation of the current carriers and supporters of the id ea of nationalis $m$ in the context of spiritual evolution have also been a source of anti-Islamis m and the West. People of the process fluctuated significantly in terms of psychological motivations and goals between the extreme positions of Westernization (Naqvi, 1983: 20-25). In spite of all these things because they have inherent weaknesses finally they fall into Christian intellectuals category or Westernized Muslim of the world and Iran (Movaseghi, 1983: 
96). They sought to create distance between the Iranian and Islam which was Iran's national foundation and ingrained through the ages of time together so that they almost become impossible and non -rational to separate them from each other because these two concepts constitutes the name of Islamic Iran representing a consistent identity. Contemporary Iranian and Islamic intellectual, Morteza Motahhari in this case writes: our history, our literature, our policy judgment our judiciary, our culture, our social Sean, finally, everything we do has been associated with this religion (Is lam) with the religion (Motahari, 1986: 50).

\section{Conclusion}

As stated earlier, in the reign of Reza Shah, Nationalism was crystallized in various forms, including archaism; patriotism and homeland friendship integrated along with a mixture of West-orientation and Zoroastrian in history books. Devoting many pages as ancient history and highlights of the period mentioned by praises of kings and their characters, especially considering that span borders in order to present a glorious past (with hyperbole and exaggeration) of Iran was important to give a sense of racial superiority of the Aryan race and Aryan pride and an emphasis on primary red -white supremacist and Iranians affinity to the West was regarded as the common point of White Aryan race and differentiation of Iranians with Muslims, especially the Arab nations, in history books, magazines, newspapers and seven letters, and a reflection of archaism and West-oriented thinking of the government.

That the link between Persian language and homeland patriotism and friendship with King and archais $m$ mean that a homeland lover should worship the king was embedded in the texts.

As a result, designers' idea of nationalism and archais $m$ in the period of Reza Shah was in the wake of a new cultural identity in the face of Islamic culture which mostly had radical aspects of the West that was based on secularis $\mathrm{m}$. These elite because of the lack of strength and rigorous theoretical focus and clarity had no deep and comprehensive understanding and knowledge of the principles and values of the West and its civilization and methodological considerations. They were affected by superficial attitude to the phenomena and neglect the fundamentals of the basic contradictions in the views and opinions of their own; but tried to conceal the basic contradictions to the next generation by entering politics. The ruling of the majority Muslim culture, made it impossible to cross at once, so at first they tried to enliven nationalism and the spirit of archais $\mathrm{m}$ in Iran by appealing to the sanctity in Farsi and national prejudices and challenge the Islamic culture by its enlarging and, if successful, and fading the influence and predominance of Islamic culture, attempt to alternative culture, since ancient Iranian culture was associated with generalities and complex and far-fetched principles, with the aura of story-telling and legends and didn't have a comprehensive plan and was more of a slogan and maybe missionaries were not aware of the consequences of this way of thinking because they didn't try it in real political worlds. Perhaps it was also considered deliberately as a solvent for promoting the dominance of western culture and a serious fight with Is lamic tradition in Iran in books, newspapers, weekly magazin es etc showed that it is not coincidence, but rather a deliberate and purposeful plan. However, the research can be claimed that these efforts institutionalized and consolidated concepts of homeland (Iran) and people (the Iranian nation).

\section{Refernces}

Abrahamian, Y. (2006). Iran Between Two Revolutions, Translated by: Gol Mohammadi, Ahmad, and Mohammad Ibrahim Fattahi. $11^{\text {th }}$ Pub.Tehran, Nei Pub.

Akbari, M. A. (2006). Genealogy of Iran's New Identity, first pub. Tehran. Cultural and Scientific Pub.

Ashuri, D. (1998). Political Encyclopedia (6th ed.). Tehran,Morvarid Pub.

Avari, P. (2010). Iran History of Pahlavi Era, Translated by: SaghebGhar, Morteza, Tehran, Neil Pub.

Ed mit, F. (1979). The perspectives of Mirza Aqa Khan Kermani. Tehran, Payam Pub.

Foroughi, M. A. (1929). A Brief History of Iran (7th ed.). Tehran, Pres s Central, Saeadat.

Foroughi, M. A. (1934, February). Ferdowsi 's venerable statu. Armagan Journal, (114).

Iqbal, A. (1966). Briefperiods of Iranian history (2nd ed.).Tehran, Saeadat Press.

Kasrawī, S. A. (1944). Clean Language, Unique, No where.

Kazem Zadeh, H. (1926). Religion, Nationality. Iranshahr Journal, (V).

Madani, A. B. (1996). obstacles to economic development (Compared with Japan). Tehran, Shahrabi.

Moore, B. (1979). Social Origins of Dictatorship and Democracy. Translated by Hussein Bshryh, Tehran, center of Academic Publishing. 
Moshfegh Kazemi, M. (1929). The impossibility of revolution with the current situation the need for the emergence of a new dictator and Science. A journal of Farangestan, (1).

Motahari, M. (1986). mutual service of Islam and Iran (14th ed.). Tehran, Sadra.

Movassaghi, A. (2003). Contemporary Islamic Movements (5th ed.). Qom, Mehr Pub.

Nafisi, S. (1967). Contemporary History of Iran. Tehran, Ferdowsi Bookstore.

Naghavi, A. M. (1983). Sociology of Westernization. Tehran, Amir Kab ir.

Qavim, A. A. Kh. (1929). The Elementary Third and Fourth Date. Tehran. Taraghi Pub.

Ramzi, S. H. (1929). Preliminary date of Iran. Tehran, The Islamia seminary library.

Sahyjy, H. (1942). Education Order. Tehran, Pharos Pub.

Shabani, R. (2003). the Iranian book (excerpts Iran). Tehran, Alhda international publications.

Sheibani, A. (1940). History. Tehran, Melli Bank Pub.

Yasemi, R. (1933). history of the fifth and sixth (11th ed.). Tehran, printing press company.

\section{Copyrights}

Copyright for this article is retained by the author(s), with first publication rights granted to the journal.

This is an open-access article distributed under the terms and conditions of the Creative Commons Attribution license (http://creativecommons.org/licenses/by/4.0/). 